\title{
Edge Effects on Avian Diversity and Density of Native Grass Conservation Buffers
}

\author{
Heidi L. Adams ${ }^{1, *}$, L. Wes Burger, Jr. ${ }^{2}$ and Sam Riffell ${ }^{2}$ \\ ${ }^{I}$ School of Forestry, Louisiana Tech University, Ruston, LA 71272, USA; ${ }^{2}$ Department of Wildlife, Fisheries and Aquac- \\ ulture, Mississippi State University, Mississippi State, MS 39762, USA
}

\begin{abstract}
Conservation Reserve Program Conservation Practice 33 (CP33: Conservation Buffers for Upland Birds) provides habitat for grassland birds in agriculture-dominated landscapes. However, landscape context and adjacency of other land covers may influence colonization, occupancy, and reproductive performance of breeding grassland birds in buffers. Our objective was to determine how edge effects influence diversity and density of breeding grassland birds in CP33 buffers. Data collected during transect surveys in CP33 buffers at a privately-owned farm in Clay County, Mississippi, USA during the 2007-2009 breeding seasons indicated that buffers with a woody edge had the least diversity and density of grassland and facultative grassland birds. Dickcissels (Spiza americana), the most abundant grassland bird species detected in buffers, had a lower density in woodland-bordered buffers than in grassland-bordered buffers. Red-winged Blackbirds (Agelaius phoeniceus) had a lower density in buffers adjacent to woodlands than buffers adjacent to developed areas and those bordered on both sides by crop fields. Conversely, Indigo Buntings, (Passerina cyanea) a woodland edge species, had the greatest density in woodland-bordered buffers when compared to buffers adjacent to grassland and developed areas. These results demonstrate that adjacency influences colonization processes and conservation design should explicitly incorporate local landscape context in field and farm-scale conservation plans. Where conservation of obligate grassland birds is a primary objective of native grass conservation buffers, avoidance of buffer establishment adjacent to woodlands may maximize environmental services as measured by grassland bird diversity and density.
\end{abstract}

Keywords: Agelaius phoeniceus, avian density, avian diversity, conservation buffers, edge effects, Passerina cyanea, Spiza americana.

\section{INTRODUCTION}

Conversion of North American grasslands into agricultural production systems has been one of the greatest threats to grassland birds [1]. Arable, fertile soils characteristic of grasslands are ideal for crop production, making these habitats fewer, smaller, and more isolated as they are plowed and planted with cereal and grain crops [2]. Because of this habitat loss, grassland birds are forced to use less suitable cropland and field margins as breeding and wintering sites [3]. Furthermore, continued intensification of agricultural systems will exacerbate habitat loss and degradation in agricultural systems $[3,4]$.

Because a reversion to less intensive agricultural practices across North America is not realistic, Peterjohn [4] suggested that "effective conservation of farmland birds will require innovative solutions based on current agricultural practices that benefit the greatest diversity of farmland birds". Grassland bird conservation depends largely on voluntary adoption of conservation practices by agricultural producers. Strategies must consider opportunity costs of diverting land from agricultural production to conservation practices. Effective strategies require development of practices that promote profitability of a crop production system and its ecological sustainability [3].

*Address correspondence to this author at the School of Forestry, Louisiana Tech University, Ruston, LA 71272, USA; Tel: (318)257-2947;

E-mail: hadams@latech.edu
Conservation Reserve Program (CRP) Conservation Practice 33 (CP33: Habitat Buffers for Upland Birds) provides habitat in agriculture-dominated landscapes [5] for grassland birds, such as Dickcissels (Spiza americana), Eastern Meadowlarks (Sturnella magna), and Northern Bobwhites (Colinus virginianus), all of which have experienced population declines throughout the United States in recent decades [6]. Under this practice, buffers 9.1-36.5 m wide are established around crop fields and planted to native warmseason grasses, legumes, and shrubs [5]. In turn, landowners receive a \$10/acre/year sign-up incentive payment, a countyand soil-specific per-acre annual rental payment, a 50\% costshare for establishment costs, and a practice incentive payment of $40 \%$ of approved establishment costs [5]. Encouraging adoption of buffer practices would contribute to habitat and population goals defined in state, regional, and national conservation initiatives designed to ameliorate these declines (e.g., Northern Bobwhite Conservation Initiative, Partners in Flight, North American Bird Conservation Initiative).

Patch context and adjacencies may serve as proximate and ultimate cues that influence settling response and colonization by grassland birds. Grassland birds may be negatively influenced by habitats that share an edge with CP33 buffers, and thus avoid these habitats. In Vermont, for example, Bobolink (Dolichonyx oryzivorus) and Savannah Sparrow (Passerculus sandwichensis) place nests in open areas away from edges [7]. In Illinois, fewer Dickcissel and Eastern Meadowlark nests were located within $100 \mathrm{~m}$ of wooded 
edges compared to beyond $100 \mathrm{~m}$ in an agriculture landscape [8]. These habitat selection processes based on proximate cues (i.e., proximity to other habitats) may be shaped by ultimate factors such as nest predation rates. In remnant prairies of Missouri, simulated ground nests within $60 \mathrm{~m}$ of woody cover experienced greater predation than those farther from woody cover [9]. Thus, it is important to determine the effect various types of edge have on breeding grassland birds in CP33 buffers to inform conservation designs in agricultural systems.

Our objective was to determine how edge effects influence diversity and density of breeding grassland birds in CP33 buffers. Results from this study will assist land managers with selecting land for enrollment in CP33 that will maximize producers' conservation goals while minimally impacting crop production, as well as assist with development and refinement of United States Department of Agriculture (USDA) Natural Resource Conservation Service (NRCS) Practice Standards, documentation of ecological benefits of federally incentivized conservation practices, and enhancement of wildlife benefits in agriculture-dominated landscapes.

\section{STUDY AREA}

We collected data at a 2,104-ha, privately-owned farm in Clay County, Mississippi, USA, with a 587-ha cattle operation and 486 ha in rowcrop production (Fig. 1). In spring 2005, 79 ha at the farm were enrolled in CP33 and buffers 18.2 or $36.5 \mathrm{~m}$ wide were established around the perimeter of 14 crop production fields. Established vegetation in these buffers were comprised of native warm-season grasses, such as big bluestem (Andropogon gerardii), little bluestem (Schizachyrium scoparium), and indiangrass (Sorghastrum nutans), and forbs, like partridge pea (Chamaecrista fasciculata), black-eyed susan (Rudbeckia hirta), and maximilian sunflower (Helianthus maximiliani). Because a concurrent study was being conducted to determine effects of periodic disturbance on grassland birds [10], only undisturbed buffers at the farm were used to determine edge effects on birds to avoid confounding between disturbance and edge effects (43 undisturbed buffers in 2007, 36 in 2008, 26 in 2009).

\section{METHODS}

\section{Bird Surveys}

To estimate grassland bird diversity and density in the buffers, we used distance sampling techniques which incorporate decreasing probability of detection with increasing distance from an observer [11]. Line transects that were 200 $\mathrm{m}$ long and ran parallel to a buffers' long axis were established in the buffers ( 1 transect/buffer). Line-transect surveys were conducted by a single observer between 0530-1000 (CST) on mornings with no precipitation and wind speeds less than $15 \mathrm{mph}$ [12]. The observer traveled at a rate of 10 $\mathrm{m} / \mathrm{min}$, recording detected birds in 1 of 4 distance bands (0-5 m, 5-10 m, 10-15 m, 15-20 m). A record was made of all birds regardless of detection method (e.g., flushing from ground or nest, observed bird perching in buffer). Temperature, percent cloud coverage, and wind speed at time of detection were also recorded. Transects were visited 6 times during each breeding season (twice monthly, May-July) from 2007 to 2009.

\section{Statistical Analyses}

We classified non-crop edges of buffers as woodland (2007, $n=20 ; 2008, n=16 ; 2009, n=12)$, grassland (2007, $n=9 ; 2008, n=10 ; 2009, n=6$ ), developed (e.g., roads; 2007, $n=12 ; 2008, n=9 ; 2009, n=7$ ), or crop (buffer was bordered on both sides by crop production fields; 2007, $n=$ $2 ; 2008, n=1 ; 2009, n=1)$. All buffers by definition had at least one crop edge.

We estimated avian diversity in CP33 buffers for each year of this study using Shannon's Diversity Index [13]. We calculated density indices based on type of non-crop edge using mean detections/ha for birds classified as grassland or facultative grassland species. We used general linear models in SAS PROC MIXED [14] to compare diversity indices with year as a repeated measure and field as a random effect using $\alpha=0.05$. Significant results were evaluated further using a Welch t-test, also with $\alpha=0.05$.

We used conventional distance sampling techniques in Program Distance 6.0 [15] to estimate detection functions of birds in buffers based on type of non-crop edge. Detection functions for species with more than 100 detections [Dickcissels, Red-winged Blackbirds (Agelaius phoeniceus), and Indigo Buntings (Passerina cyanea)] were individually estimated. Species with less than 100 detections provided insufficient data to generate robust estimates of a detection function [11]. We used Akaike's Information Criterion (AIC) to determine the best fit detection function from appropriate key functions (half-normal or uniform) with possible cosine or simple polynomial adjustment terms. Model selection was based on the least AIC value and goodness of fit of a model.

Model selection results most frequently supported the uniform key function when data were partitioned based on type of non-crop edge (Tables 1 and 2). Excluding combined density estimates for grassland and facultative grassland birds in buffers bordered by grassland, inclusion of series expansion adjustments did not improve model precision. Detection probabilities ranged from $0.88-1.0$. Thus, we assumed $100 \%$ detection and estimated buffer- and yearspecific avian density in buffers by calculating mean number of avian detections/ha. We evaluated potential differences in avian density based on type of non-crop edge, using general linear models in SAS PROC MIXED [14] with further evaluation with a Welch t-test, again using $\alpha=0.05$.

\section{RESULTS}

We detected 26 avian species in CP33 buffers during the 2007-2009 breeding seasons: 5 were grassland species; 6 were facultative grassland species; 9 were edge species that use grassland-woodland interfaces; 3 were woodland species; 3 were species that prefer urban or developed areas (Table 3). The 3 most frequently detected species were Dickcissels (grassland species, 427 detections), Red-winged Blackbirds (facultative grassland species, 338 detections) and Indigo Buntings (edge species, 252 detections).

There was no significant year*edge interaction influencing combined diversity of grassland and facultative grassland birds in CP33 buffers ( $F=0.72, \mathrm{df}=6$ and $62.4, P=0.638)$. Year was not related to grassland and facultative grassland combined avian diversity in the buffers $(F=0.29, \mathrm{df}=2$ and 


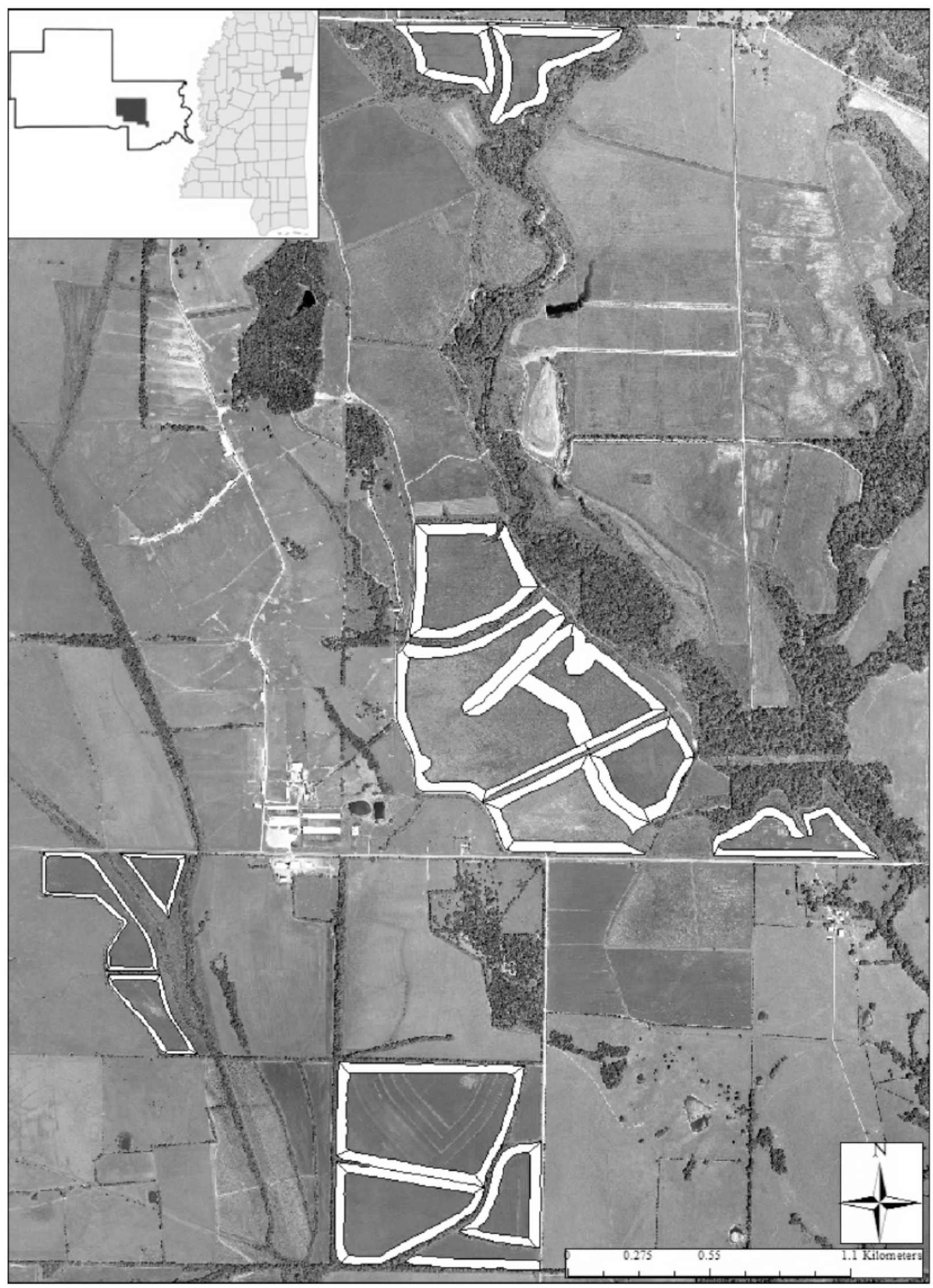

Fig. (1). Aerial photograph of agricultural land enrolled in Conservation Reserve Program Conservation Practice 33 (CP33: Habitat Buffers for Upland Birds) at a privately-owned farm in Clay County, Mississippi, USA. CP33 buffers in the photograph are highlighted in white. 
Table 1. Estimated densities (birds/ha; D), detection function (f(0)), number of parameters (K), Akaike's information criterion (AIC), $\triangle$ AIC, and probability of detection (p) for grassland and facultative grassland birds combined that were detected in CP33 buffers at a privately-owned farm in Clay County, Mississippi, USA, 2007-2009.

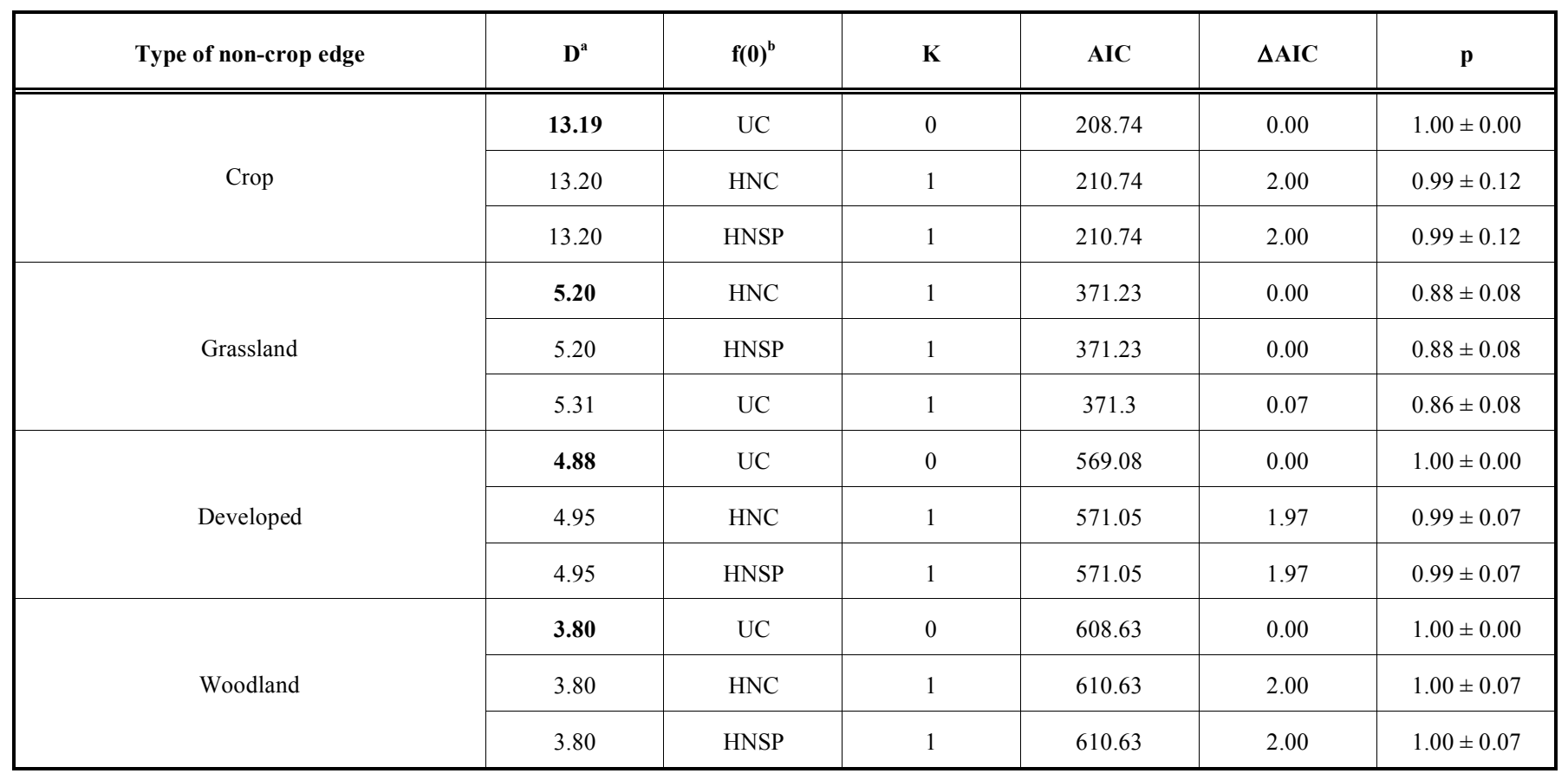

${ }^{a}$ Density of top model for each type of non-crop edge bolded.

${ }^{\mathrm{b} U C}$ : Uniform distribution, cosine adjustment; HNC: half-normal distribution, cosine adjustment; HNSP: half-normal distribution, simple polynomial adjustment.

63.7, $P=0.750$ ). There was no significant difference in grassland and facultative grassland combined avian diversity in regard to type of non-crop edge $(F=2.78, \mathrm{df}=3$ and 26.5, $P=0.061)$. Non-crop edge differences, however, did approach significance. Buffers bordered on both sides by crop had the highest diversity $\left(\mathrm{H}^{\prime}=0.559 \pm 0.1961, t=2.85, \mathrm{df}=\right.$ $32.8, P=0.008)$, followed by buffers adjacent to developed areas $\left(\mathrm{H}^{\prime}=0.417 \pm 0.080, t=2.18, \mathrm{df}=32.3, P<0.001\right)$, then those bordered by grassland $\left(\mathrm{H}^{\prime}=0.285 \pm 0.081, t=\right.$ $3.53, \mathrm{df}=33.9, P=0.001$ ), and finally buffers bordered by woodland $\left(\mathrm{H}^{\prime}=0.191 \pm 0.067, t=2.86, \mathrm{df}=23.3, P=\right.$ $0.009)$.

Year and type of non-crop edge interacted to significantly influence grassland-facultative grassland avian density $(F=2.49$, df $=6$ and $51.9, P=0.034)$. In 2007 , avian density in buffers bordered on both sides by crop was greater than that in buffers adjacent to grassland $(t=3.22, \mathrm{df}=33.8$, $P=0.015)$ or woodland habitat $(t=3.41, \mathrm{df}=33.6, P=$ 0.009; Fig. 2). Buffers bordered on both sides by crop also had the greatest avian density in 2008 compared to the other 3 types of non-crop edge (developed areas, $t=6.14$, df $=$ 21.3, $P<0.001$; grassland, $t=6.19$, df $=21.4, P<0.001$, woodland, $t=6.75$, df $=22.4, P<0.001)$. The same was true in 2009 (developed areas, $t=4.15$, df $=21.6, P<0.001$; grassland, $t=4.03, \mathrm{df}=19.3, P<0.001$, woodland, $t=5.41$, $\mathrm{df}=21.4, P<0.001)$. Also in 2009, buffers adjacent to woodland habitat had significantly lower density than buffers adjacent to grassland habitat $(t=3.27, \mathrm{df}=18.1, P=$ $0.004)$ and developed areas $(t=2.53, \mathrm{df}=21.3, P=0.020)$.

There was no significant year*edge interaction $(F=1.20$, $\mathrm{df}=6$ and 66.2, $P=0.319)$ or year effect $(F=3.02, \mathrm{df}=2$ and 74.6, $P=0.055)$ with respect to Dickcissel density and edge. However, type of non-crop edge did affect Dickcissel density $(F=20.74$, df $=3$ and 37.5, $P<0.001$; Fig. 3). Dickcissel density in buffers bordered on both sides by crop was greater than those adjacent to grassland $(t=6.62, \mathrm{df}=50.6$, $P<0.001)$, developed areas $(t=7.40, \mathrm{df}=48.7, P<0.001)$, and woodland $(t=7.73, \mathrm{df}=55.4, P<0.001)$. Dickcissel density in grassland-bordered buffers did not differ from those bordered by developed areas $(t=1.08, \mathrm{df}=31.3, P=$ $0.288)$ or woodlands $(t=1.93, \mathrm{df}=30.4, P=0.467)$.

We observed no year*edge interaction on Red-winged Blackbird density in CP33 buffers $(F=2.07, \mathrm{df}=6$ and 56.8, $P=0.070$ ). These factors, however, did independently influence Red-winged Blackbird density in buffers (edge, $F=$ 3.72 , $\mathrm{df}=3$ and 33.2, $P=0.021$; year, $F=4.92$, $\mathrm{df}=2$ and $62.0, P=0.010$; Fig. 3). Buffers bordered on both sides by crop had a greater Red-winged Blackbird density than buffers adjacent to grassland $(t=2.23, \mathrm{df}=36.7, P=0.032)$ or woodland $(t=2.55$, df $=40.0, P=0.015)$. Grasslandbordered buffers did not differ significantly from woodlandbordered buffers with respect to mean Red-winged Blackbird density $(t=0.44, \mathrm{df}=30.0, P=0.660)$. Buffers with developed areas at the edge had a greater Red-winged Blackbird density than woodland-bordered buffers $(t=2.59$, $\mathrm{df}=34.2$, $P=0.014)$.

Indigo Bunting density in buffers was only influenced significantly by type of non-crop edge $(F=7.38, \mathrm{df}=3$ and 46.5, $P<0.001$; Fig. 3). Overall, woodland-bordered buffers had a greater Indigo Bunting density than buffers adjacent to grassland $(t=3.75, \mathrm{df}=39.8, P=0.001)$ and developed areas $(t=3.86, \mathrm{df}=40.8, P<0.001)$. 
Table 2. Estimated densities (birds/ha; D), detection function (f(0)), number of parameters (K), Akaike's information criterion (AIC), $\triangle$ AIC, and probability of detection (p) for Dickcissels, Red-winged Blackbirds, and Indigo Buntings detected in CP33 buffers at a privately-owned farm in Clay County, Mississippi, USA, 2007-2009.

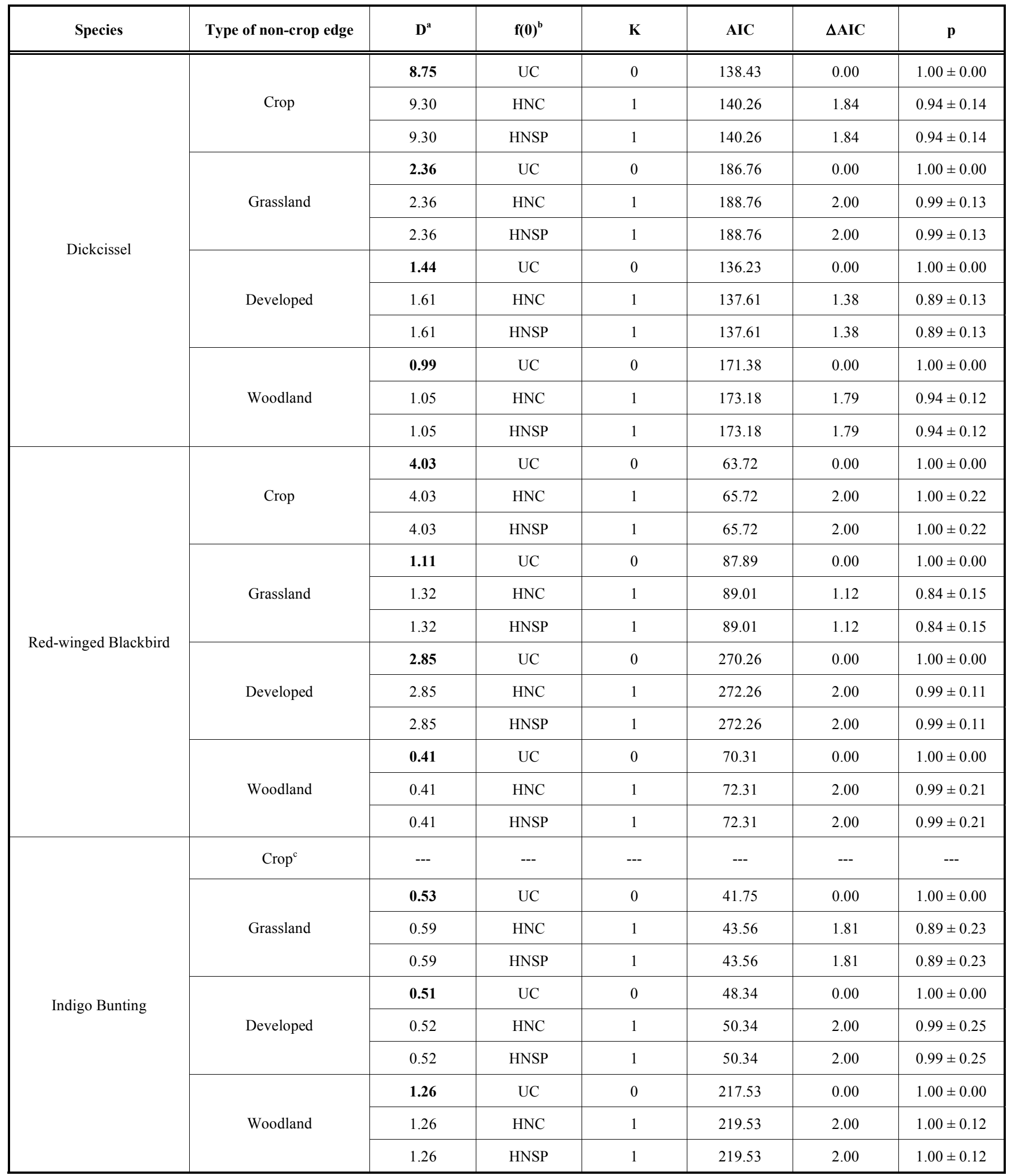

${ }^{a}$ Density of top model for each type of non-crop edge bolded.

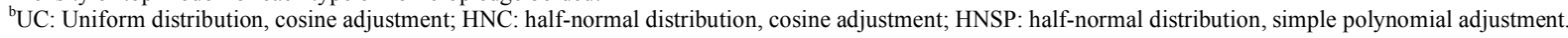
${ }^{c}$ No data available to be analyzed. 
Table 3. Avian species detected during transect surveys in CP33 buffers at a privately-owned farm in Clay County, Mississippi, USA, 2007-2009.

\begin{tabular}{|c|c|c|}
\hline \multicolumn{2}{|l|}{ Species $^{\mathrm{a}}$} & Number of detections \\
\hline & Dickcissel (Spiza americana) & 427 \\
\hline & Eastern Meadowlark (Sturnella magna) & 8 \\
\hline & Northern Bobwhite (Colinus virginianus) & 8 \\
\hline & Grasshopper Sparrow (Ammodramus savannarum) & 1 \\
\hline \multicolumn{3}{|c|}{ Facultative grassland } \\
\hline & Red-winged Blackbird (Agelaius phoeniceus) & 338 \\
\hline & Mourning Dove (Zenaida macroura) & 18 \\
\hline & Brown-headed Cowbird (Molothrus Ater) & 3 \\
\hline & Loggerhead Shrike (Lanius ludovicianus) & 1 \\
\hline \multicolumn{3}{|l|}{ Edge } \\
\hline & Indigo Bunting (Passerina cyanea) & 252 \\
\hline & Blue Grosbeak (Guiraca caerulea) & 35 \\
\hline & Northern Cardinal (Cardinalis cardinalis) & 28 \\
\hline & Field Sparrow (Spizella pusilla) & 17 \\
\hline \multicolumn{3}{|c|}{ Woodland } \\
\hline & Ruby-throated Hummingbird (Archilochus colubris) & 8 \\
\hline & Carolina Chickadee (Poecile carolinensis) & 3 \\
\hline & Blue-gray Gnatcatcher (Polioptila cerulea) & 1 \\
\hline \multicolumn{3}{|c|}{ Urban-associated } \\
\hline & Northern Mockingbird (Mimus polyglottos) & 8 \\
\hline & Barn Swallow (Hirundo rustica) & 3 \\
\hline & Purple Martin (Progne subis) & 1 \\
\hline
\end{tabular}

${ }^{a}$ Species classifications based upon Hamel [16], Vickery et al. [17].

\section{DISCUSSION}

Although there was no significant difference in grassland and facultative grassland combined avian diversity in regards to type of non-crop edge, differences did approach significance, suggesting there may be a moderate biological effect influencing diversity. Furthermore, grassland-facultative grassland bird density was least in buffers adjacent to woodland habitat during 2008 and 2009. Taking into consideration a strong biological potential of an edge effect on diversity, as well as the significant influence of edges on density, these results indicate that grassland and facultative grassland birds prefer buffers that are not adjacent to woodland habitat. 


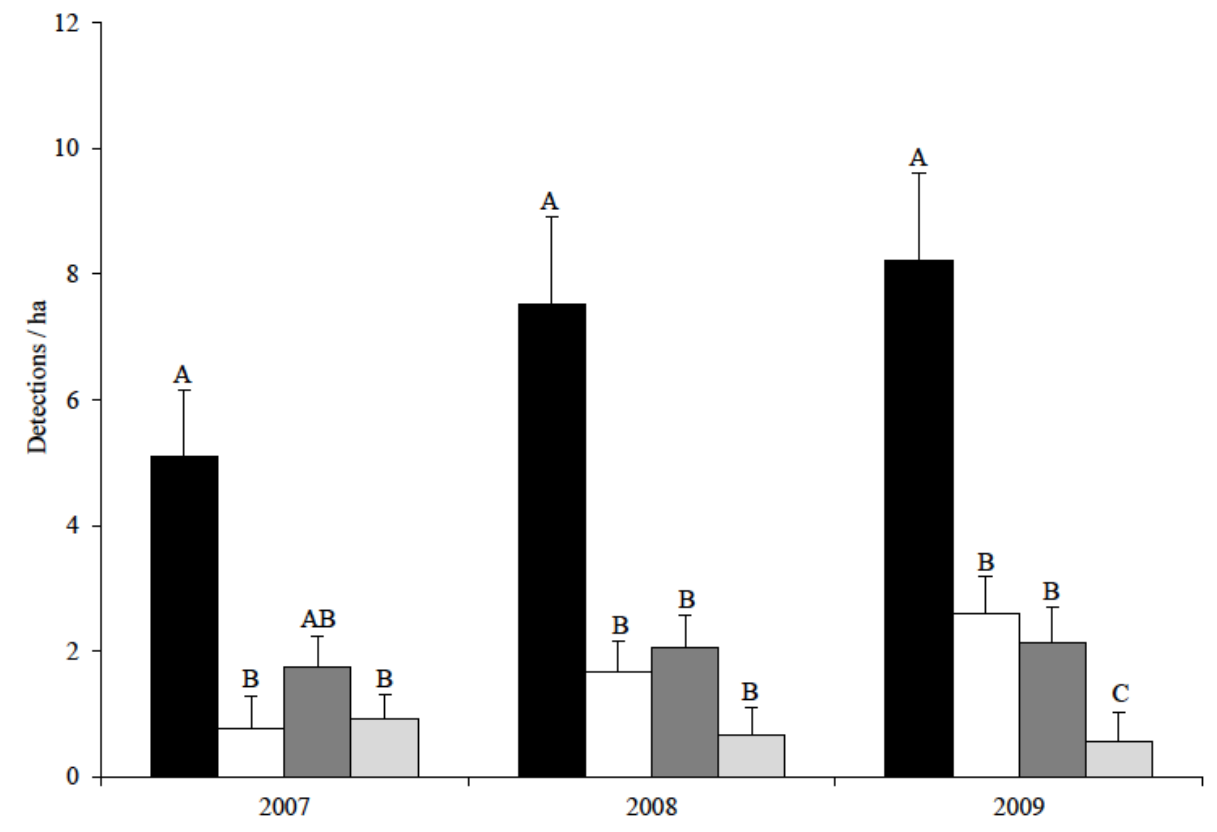

Fig. (2). Grassland and facultative grassland bird density (mean \pm standard error) in buffers enrolled in Conservation Reserve Program Conservation Practice 33 (CP33: Conservation Buffers for Upland Birds) at a privately-owned farm in Clay County, Mississippi, USA, 2007-2009. Types of non-crop edge represented are crop (black), grassland (white), developed areas (dark gray), and woodland (light gray).

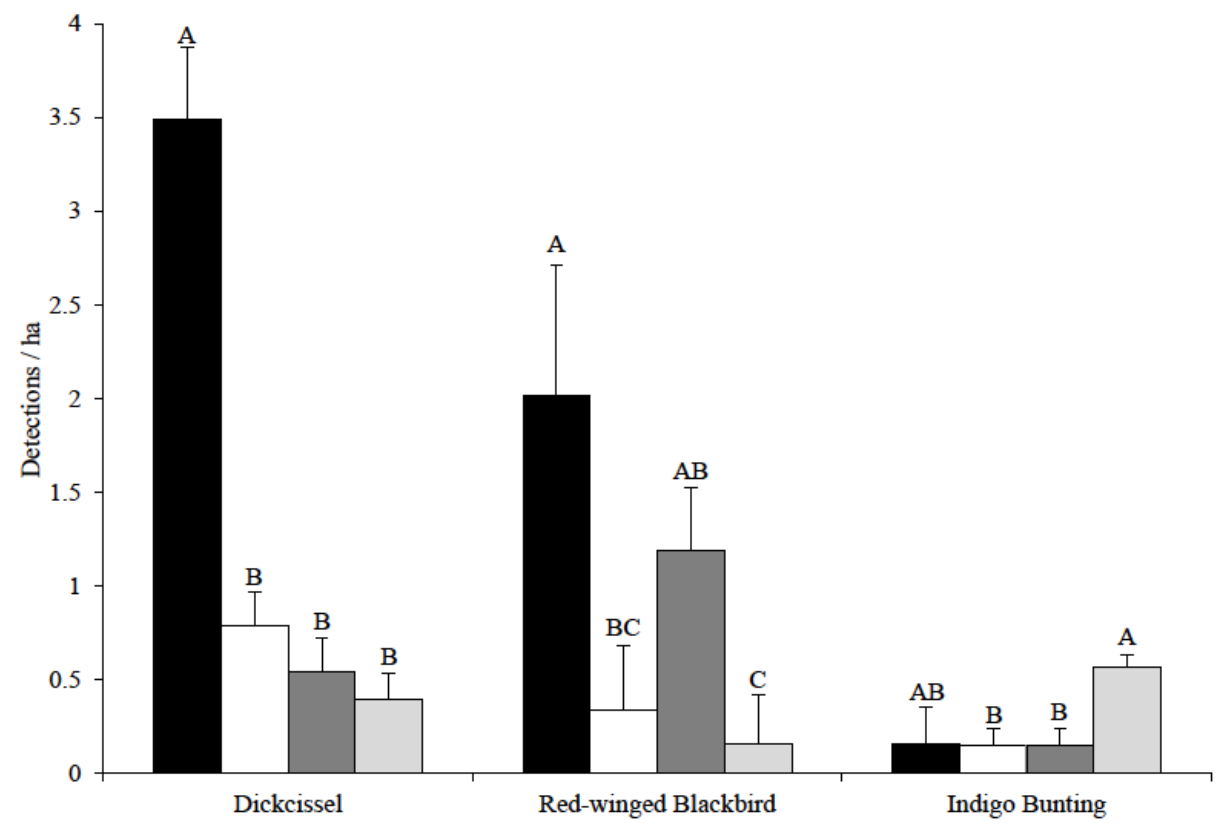

Fig. (3). Dickcissel, Red-winged Blackbird, and Indigo Bunting densities (mean \pm standard error) in buffers enrolled in Conservation Reserve Program Conservation Practice 33 (CP33: Conservation Buffers for Upland Birds) at a privately-owned farm in Clay County, Mississippi, USA, 2007-2009. Types of non-crop edge represented are crop (black), grassland (white), developed areas (dark gray), and woodland (light gray).

Several other studies have documented the woody edge effect on grassland birds in the adjacent open habitats. In Nebraska, for instance, Grasshopper Sparrows (Ammodramus savannarum) avoided nesting in grassland areas that were within $50 \mathrm{~m}$ of a wooded edge [18]. Similarly, density of Bobolinks in Wisconsin was negatively associated with proximity to woody vegetation [19]. Abundances of Savannah Sparrows, Western Meadowlarks (Sturnella neglecta), Sedge Wrens (Cistothorus platensis), and Grasshopper Sparrows in South Dakota were negatively associated with woody vegetation at grassland edges [20]. In Michigan, grassland bird fledging success increased from $20-30 \%$ near field-forest edges to $60-70 \%$ for nests farther from them [21].

Nests in close proximity to grassland-woody edges may have increased risk of predation. Woody edges can have a greater abundance of predators, which may reduce survival and reproductive ability of grassland birds [22]. In our study, nests were depredated by snakes, such as the southern black 
racer (Coluber constrictor priapus), mammals, birds, and fire ants (Solenopsis spp.) [10]. In southwestern Missouri, Dickcissel and Henslow's Sparrow (Ammodramus henslowii) nest success was greater beyond $50 \mathrm{~m}$ of a woody edge [23]. Bobolinks and Savannah Sparrows in Vermont had greater nest densities $50 \mathrm{~m}$ or more from a wooded edge; Savanah Sparrows daily nest survival rate was positively correlated with increasing distance from a wooded edge [24]. There is also an increased risk of nest parasitism by Brownheaded Cowbirds (Molothrus ater) near woody edges. Winter et al. [23] found nest parasitism of Dickcissel nests in southwest Missouri was greater within $50 \mathrm{~m}$ of a woody edge. Similarly, Brown-headed Cowbird parasitism was greatest within $50 \mathrm{~m}$ of woody edges in Kansas compared to nests $100 \mathrm{~m}$ or more from an edge [25]. Finally, Bollinger and Gavin [26], who found that Bobolink nest densities within $25 \mathrm{~m}$ of a forest edge in New York were less than expected, suggested there is increased interspecific competition, less desirable vegetation species, and microclimate differences such as lower temperatures near field-forest edges.

Dickcissels are grassland specialists found frequently on CRP land [27, 28]. Dickcissel density in buffers adjacent to developed areas did not differ from buffers adjacent to grassland habitat. Though abundance of grassland birds is often negatively associated with urbanization [29, 30], this was not the case in this study. Much of the area classified as developed in this study were roads used only for farm management activities and were bordered on both sides by CP33 buffers or other grassland areas. Because of minimal traffic on these roads and availability of grassland on either side, Dickcissels may not have responded negatively to them.

Though Dickcissel density was not significantly greater in buffers adjacent to grassland than those adjacent to woodland, the difference was great enough to consider a possible biological influence of woodland on Dickcissels. Dickcissel densities are often negatively associated with woodlands. In Kansas, Dickcissel abundance in grasslands decreased with an increasing amount of woodland areas and edges [31]. Because woodlands adjacent to grassland habitat can provide cover for predators and nest parasites, breeding Dickcissels may avoid these areas to ensure the survival of their young.

Red-winged Blackbird density in buffers adjacent to developed areas did not differ from that adjacent to grassland habitat. Red-winged Blackbird density was least in buffers adjacent to woodland, especially when compared to densities in crop-bordered buffers and those bordered by developed areas. Red-winged Blackbird densities in Maryland were least in strip habitats adjacent to forest edges [32]. Though Red-winged Blackbirds are capable of breeding in many habitat types, they are still susceptible to risks of predation and nest parasitism associated with woody vegetation. In Wisconsin, for example, Red-winged Blackbird nests located farther from woody vegetation were less likely to be parasitized by Brown-headed Cowbirds [33].

Both Dickcissels and Red-winged Blackbirds had high densities in buffers with crop production fields on both sides. Crop fields can be optimal foraging locations for birds because of availability of insect prey. Furthermore, birds that forage in these areas can be beneficial to land managers by feeding on potential pest insects $[34,35]$. Several studies have documented potential for these species to cause damage to agricultural crops, but this was not likely an issue in our study area. Crop damage by Dickcissels occurs primarily in Latin America where wintering birds form large flocks and feed on cereal crops [36]. Control methods of Dickcissels in these areas have contributed to the dramatic drop in population size of this species [36]. Though Red-winged Blackbirds have been implicated in crop losses [37], we did not observe any large flocks of blackbirds or crop damage caused by either Dickcissels or Red-winged Blackbirds.

Indigo Buntings require woodlands and grasslands in close proximity to one another, and are found often in fieldforest edges [38]. They can also be found in shrubby areas, as well as in weedy fields [39]. In this study, Indigo Bunting density in buffers adjacent to woodland was greater than in buffers adjacent to any other type of non-crop edge. This difference was statistically significant when comparing buffers adjacent to grassland and developed areas. Similarly, Indigo Bunting densities in Maryland were greater in strip vegetation habitats bordered by forests than in those adjacent to grassland [32]. In the Mississippi Alluvial Valley, Indigo Buntings were detected frequently in buffers but benefited more from those adjacent to woodland [40].

\section{Management Implications}

Non-crop herbaceous natural communities provide essential and scarce habitat in modern agricultural systems. Conservation practices, such as CP33 buffers, that create seminatural grassland habitat with relatively minor change in primary land use can have a disproportionate effect on local and regional bird populations [41]. Design of managed landscapes that include these elements must take into account plant materials, vegetation structure, patch size, patch adjacencies, and landscape context.

Agricultural systems often consist of diverse types of land cover, all of which could either enhance or reduce a CP33 buffer's ability to support grassland bird populations. Based on results of this study, type of non-crop edge influenced diversity and density of grassland birds in buffers during the breeding season. To maximize the potential of CP33 buffers in supporting grassland bird populations, landowners should avoid buffer establishment in areas with woodland cover. Buffer quality could be further enhanced if they are established in areas with more grass or early-successional herbaceous cover, such as grasslands, pastures, or hayfields. This would encourage grassland bird use of buffers, as well as reduce risks associated with predators and nest parasites.

\section{CONFLICT OF INTEREST}

The authors confirm that this article content has no conflict of interest.

\section{ACKNOWLEDGEMENTS}

Financial support for this study was provided by the Mississippi Agricultural and Forestry Experiment Station, the USDA NRCS Agricultural Wildlife Conservation Center, the Mississippi State University Forest and Wildlife Research Center, and the Mississippi State University College of Forest Resources. We thank B. Bryan Farms for access to the 
study area and L. Woodall for logistical support. We also appreciate assistance provided by J. Dollar, K. Evans, S. Hale, R. Kaminski, R. Kissell, J. Martin, K. Mitchell, B. Strickland, and many undergraduate research technicians. This publication is dedicated in memory of our coauthor, colleague, and friend, Dr. Sam Riffell.

\section{PATIENT'S CONSENT}

Declared none.

\section{REFERENCES}

[1] Brennan LA, Kuvlesky Jr. WP. North American Grassland Birds: An unfolding conservation crisis? J Wildl Manage 2005; 69: 1-13.

[2] Reinking DL. Fire regimes and avian responses in the central tallgrass prairie. Stud Avian Biol 2005; 30: 116-26.

[3] Askins RA, Zuckerberg B, Novak L. Do the size and landscape context of forest openings influence the abundance and breeding success of shrubland songbirds in southern New England? Forest Ecol Manage 2007; 250: 137-47.

[4] Peterjohn BG. Agricultural Landscapes: Can they support healthy bird populations as well as farm products? Auk 2003; 120: 14-9.

[5] Burger Jr. LW, McKenzie D, Thackston R, Demaso SJ. The role of farm policy in achieving large-scale conservation: Bobwhite and Buffers. Wildl Soc B 2006; 34: 986-93.

[6] Sauer JR, Hines JE, Fallon J. The North American breeding bird survey, results and analysis 1966-2007. Version 5.15.2008. Laurel, Maryland: USGS Patuxent Wildlife Research Center 2008.

[7] Keyel AC, Strong AM, Perlut NG, Reed JM. Evaluating the roles of visual openness and edge effects on nest-site selection and reproductive success in grassland birds. Auk 2013; 130: 161-70.

[8] Walk JW, Kershner EL, Benson TJ, Warner RE. Nesting success of grassland birds in small patches in an agricultural landscape. Auk 2010; 127: 328-34.

[9] Burger LD, Burger Jr. LW, Faaborg JR. Effects of prairie fragmentation on predation of artificial nests. J Wildl Manage 1994; 58: 249-54.

[10] Adams HL, Burger Jr. LW, Riffell S. Disturbance and landscape effects on avian nests in agricultural conservation buffers. J Wildl Manage 2013; 77: 1213-20.

[11] Buckland ST, Anderson DR, Burnham KP, Laake JL, Borchers DL, Thomas L. Introduction to distance sampling. New York: Oxford University Press 2001.

[12] Smith MD, Barbour PJ, Burger Jr. LW, Dinsmore SJ. Breeding bird abundance and diversity in agricultural field borders in the Black Belt Prairie of Mississippi. Proc Southeast Assoc Fish Wildl Agencies 2005; 59: 43-56.

[13] Shannon CE, Weaver W. The mathematical theory of communication. Champaign: Illini Books, Champaign 1963.

[14] SAS Institute Inc. 9.2 Help and Documentation. Cary: SAS Institute Inc. 2010

[15] Thomas L, Buckland ST, Rexstad EA, et al. Distance software: design and analysis of distance sampling surveys for estimating population size. J Appl Ecol 2010; 47: 5-14.

[16] Hamel PB. Land Manager's Guide to Birds of the South. Chapel Hill: Nature Conservancy 1992.

[17] Vickery PD, Tubaro PL, Cardoso da Silva JM, Peterjohn BG, Herkert JR, Cavalcanti RB. Conservation of Grassland Birds in the Western Hemisphere. Stud Avian Biol 1999; 19: 2-26.

[18] Delisle JM, Savidge JA. Reproductive success of grasshopper sparrows in relation to edge. Prairie Nat 1996; 28: 107-13.
[19] Ribic CA, Sample DW. Associations of grassland birds with landscape factors in Southern Wisconsin. Am Midl Nat 2001; 146: 10521.

[20] Bakker KK, Naugle DE, Higgins KF. Incorporating landscape attributes into models for migratory grassland bird conservation. Conserv Biol 2002; 16: 1638-46.

[21] Gates JE, Gysel LW. Avian nest dispersion and fledging success in field-forest ecotones. Ecology 1978; 59: 871-83.

[22] Batáry P, Báldi A. Evidence of an edge effect on avian nest success. Conserv Biol 2004; 18: 389-400.

[23] Winter M, Johnson DH, Faaborg J. Evidence for edge effects on multiple levels in Tallgrass prairie. Condor 2000; 102: 256-66.

[24] Perkins DG, Perlut NG, Strong AM. Minor fitness for edge avoidance in nesting grassland birds in the Northeastern United States. Auk 2013; 130: 512-9.

[25] Jensen WE, Finck EJ. Edge effects on nesting dickcissels (Spiza americana) in relation to edge type of Remnant Tallgrass Prairie in Kansas. Am Midl Nat 2004; 151: 192-9.

[26] Bollinger EK, Gavin TA. Responses of Nesting Bobolinks (Dolichonyx oryzivorus) to Habitat Edges. Auk 2004; 121: 767-76.

[27] Herkert JR. Response of bird populations to farmland set-aside programs. Conserv Biol 2009; 23: 1036-40.

[28] Evans KO, Burger Jr. LW, Oedekoven CS, et al. Multi-region Response to Conservation Buffers Targeted for Northern Bobwhite. J Wildl Manage 2013; 77: 716-25.

[29] Bock CE, Bock JH, Bennett BC. Songbird abundance in grasslands at a suburban interface on the Colorado High Plains. Stud Avian Biol 1999; 19: 131-6.

[30] Riffell S, Scognamillo D, Burger LW. Effects of the conservation reserve program on Northern Bobwhite and Grassland Birds. Environ Monitor Assess 2008; 146: 309-23.

[31] Hughes JP, Robel RJ, Kemp KE, Zimmerman JL. Effects of habitat on dickcissel abundance and nest success in conservation reserve program fields in Kansas. J Wildl Manage 1999; 63: 523-9.

[32] Morgan KA, Gates JE. Bird population patterns in forest edge and strip vegetation at Remington Farms, Maryland. J Wildl Manage 1982; 46: 933-44

[33] Clotfelter ED. What cues do brown-headed Cowbirds use to locate red-winged blackbird host nests? Anim Behav 1998; 55: 1181-9.

[34] Tremblay A, Mineau P, Stewart RK. Effects of bird predation on some pest insect populations in corn. Agric Ecosyst Environ 2001; 83: $143-52$

[35] Jones GA, Sieving KE, Jacobson SK. Avian diversity and functional insectivory on North-central Florida Farmlands. Conserv Biol 2005; 19: 1234-5.

[36] Basili GD, Temple SA. Dickcissels and crop damage in Venezuela: Defining the problem with ecological models. Ecol Appl 1999; 9: 732-9.

[37] Dolbeer RA. Ornithology and integrated pest management: Redwinged Blackbird Agelaius phoeniceus and Corn. Ibis 1990; 132: 309-22.

[38] Weldon AJ, Haddad NM. The effects of patch shape on indigo buntings: Evidence for an Ecological Trap. Ecology 2005; 86: 1422-31.

[39] Payne RB. Indigo Bunting (Passerina cyanea). In: Poole A, Ed. The Birds of North America: Ithaca, Cornell Lab of Ornithology 2006; No. 004

[40] Conover RR, Burger Jr. LW, Linder ET. Breeding bird response to field border presence and width. Wilson J Ornith 2009; 121: 54855 .

[41] Evans KO, Burger Jr. LW, Riffell SK, et al. Avian response to conservation buffers in agricultural landscapes during winter. Wildlife Soc B 2014; 38: 257-64

(C) Adams et al.; Licensee Bentham Open.

This is an open access article licensed under the terms of the Creative Commons Attribution Non-Commercial License (http://creativecommons.org/licenses/by-nc/3.0/) which permits unrestricted, non-commercial use, distribution and reproduction in any medium, provided the work is properly cited. 